\title{
The TNFalpha gene relates to clinical phenotype in alpha-I-antitrypsin deficiency
}

\author{
Alice M Wood ${ }^{1}$, Matthew J Simmonds ${ }^{1}$, Darren L Bayley ${ }^{2}$, Paul R Newby ${ }^{1}$, \\ Stephen C Gough ${ }^{1}$ and Robert A Stockley*2
}

\begin{abstract}
Address: ${ }^{1}$ Division of Medical Sciences, The Medical School, University of Birmingham, Birmingham, B15 2TT, UK and ${ }^{2}$ Lung Investigation Unit, University Hospital Birmingham, Birmingham, B15 2TH, UK

Email: Alice M Wood - alice.wood@uhb.nhs.uk; Matthew J Simmonds - m.j.simmonds@bham.ac.uk; Darren L Bayley - bayleydl@hotmail.com; Paul R Newby - p.r.newby@bham.ac.uk; Stephen C Gough - s.c.gough@bham.ac.uk; Robert A Stockley* - rob.stockley@uhb.nhs.uk

* Corresponding author
\end{abstract}

Published: II July 2008

Respiratory Research 2008, 9:52 doi:10.1186/1465-9921-9-52

This article is available from: http://respiratory-research.com/content/9/1/52

(c) 2008 Wood et al; licensee BioMed Central Ltd.

This is an Open Access article distributed under the terms of the Creative Commons Attribution License (http://creativecommons.org/licenses/by/2.0), which permits unrestricted use, distribution, and reproduction in any medium, provided the original work is properly cited.
Received: 7 May 2008

Accepted: II July 2008

\begin{abstract}
Background: Genetic variation may underlie phenotypic variation in chronic obstructive pulmonary disease (COPD) in subjects with and without alpha I antitrypsin deficiency (AATD). Genotype specific sub-phenotypes are likely and may underlie the poor replication of previous genetic studies. This study investigated subjects with AATD to determine the relationship between specific phenotypes and TNF $\alpha$ polymorphisms.
\end{abstract}

Methods: 424 unrelated subjects of the PiZZ genotype were assessed for history of chronic bronchitis, impairment of lung function and radiological presence of emphysema and bronchiectasis. A subset of subjects with 3 years consecutive lung function data was assessed for decline of lung function. Four single nucleotide polymorphisms (SNPs) tagging TNF $\alpha$ were genotyped using TaqMan ${ }^{\circledR}$ genotyping technologies and compared between subjects affected by each phenotype and those unaffected. Plasma TNF $\alpha$ levels were measured in all PiZZ subjects.

Results: All SNPs were in Hardy-Weinberg equilibrium. A significant difference in rs36I525 genotype $(p=0.01)$ and allele $(p=0.01)$ frequency was seen between subjects with and without chronic bronchitis, independent of the presence of other phenotypes. TNF $\alpha$ plasma level showed no phenotypic or genotypic associations.

Conclusion: Variation in TNF $\alpha$ is associated with chronic bronchitis in AATD.

\section{Background}

Chronic obstructive pulmonary disease (COPD) is thought to be the result of environmental triggers in genetically susceptible individuals. Although cigarette smoking is the main environmental risk factor, only about $15 \%$ of smokers develop clinically significant disease[1], suggesting other influences on disease expression. This is supported by family studies showing ancestral aggrega- tion of spirometric abnormalities both in the general population [2] and in relatives of patients with COPD [3]. Moreover, differences in rate of decline of lung function between smokers[4] suggests a gene-environment interaction.

COPD is associated with an abnormal inflammatory response in which proteases[5] and oxidants[6] play a sig- 
nificant pathogenic role. Inflammation is particularly important in systemic disease and associated co-morbidities[7]. Tumour necrosis factor alpha (TNF $\alpha$ ) is an inflammatory cytokine which is elevated in the sputum[8], bronchial biopsies[9] and circulation [10] of COPD patients. The TNF $\alpha$ gene $(T N F \alpha)$ has been investigated in several COPD phenotypes [11-14] but in general associations have been poorly replicated[13].

In AATD there is significant variation in the clinical phenotype. Although classically associated with basal panlobular emphysema, it is now recognised that multiple phenotypes typical of usual COPD occur, including centrilobular emphysema, bronchitis and bronchiectasis [15]. As in usual COPD other genetic influences may be important in determining clinical features [16-19], but no studies have examined the role of candidate genes in the full range of COPD phenotypes. Since inflammation is more marked in AATD than usual COPD [20], perhaps driven by a key interaction between AAT and TNF $\alpha$ [21], we hypothesised that variation in TNF $\alpha$ may influence clinical phenotype in AATD.

\section{Methods \\ Study design}

In this case-control association study, cases comprised subjects with AATD affected by a COPD phenotype and those unaffected acted as AATD controls. Subjects were genotyped for four tag single nucleotide polymorphisms (SNPs) selected to cover common variation in TNF $\alpha$. Genotype and allele frequency were compared between cases and controls, with adjustment for confounding variables and phenotypic overlap. Plasma TNF $\alpha$ levels were compared with SNP genotype.

\section{Study subjects}

Four hundred and twenty four unrelated Caucasian subjects from the UK national registry for AATD were studied. Ethical approval was given by the local ethics committee. All patients had a serum alpha-1-antitrypsin (AAT) level of $<11 \mu \mathrm{M}$ and PiZZ genotype confirmed by specific PCR (Heredilab, Salt Lake City, USA). None of the subjects had ever received AAT replacement.

\section{Clinical phenotyping}

A full clinical assessment including smoke exposure, presence of chronic bronchitis (defined as a productive cough for at least 3 months of at least 2 consecutive years[22]), lung function testing and high resolution CT scanning of the chest was undertaken, as described previously [23]. Annual lung function measurement allowed assessment of decline of FEV1. Linear regression was used to calculate decline over 3 years, such that the slope of the line between time zero and 3 years for each subject represented loss per year. The presence of bronchiectasis was determined as described by Naidich et al [24] by a single radiologist. The presence of emphysema was determined by the appearance of the scan and density mask analysis of slices at the level of the aortic arch (representing the upper zone) and the inferior pulmonary vein (representing the lower zone) using a threshold of -910HU. This threshold has been deemed optimal for emphysema detection[25], and validated against physiological measures in AATD [26]. Patients whose voxel index exceeded values seen in normal subjects in either zone[27] were deemed to have emphysema.

\section{Genotyping and TNF $\alpha$ quantification}

SNPs to tag TNF $\alpha$ were chosen using linkage disequilibrium (LD) data for UK Caucasians [28], according to established methods [29], revealing four tags needed to capture all SNPs with minor allele frequency $>0.05$ using a cut off of $\mathrm{r}^{2}>0.8$. DNA extraction was performed using a modified Nucleon Bacc II kit (Tepnel Life Sciences, UK) and quantified using Picogreen ${ }^{\circledast}$ (Molecular Probes Inc, UK). Genotyping was carried out using TaqMan ${ }^{\circledast}$ genotyping technologies (Applied Biosystems, UK) on an ABI7900 HT. All genotyping assays were pre-validated by the suppliers, and all plates included appropriate negative controls. Stable state plasma TNF $\alpha$ was measured using a high sensitivity ELISA ( $\mathrm{R} \& \mathrm{D}$ systems, Abingdon, UK) as described previously [30].

\section{Statistical Analysis}

Deviation from Hardy Weinberg equilibrium was checked for all SNPs. Data was analysed using SPSS (version 12, November 2003, Chicago: SPSS Inc) and haplotype analyses carried out in Haploview [31]. Comparisons of demographic and clinical features between subgroups were carried out using the Mann Whitney or t-tests, as appropriate. Genotype and allele frequency of each tag SNP was compared between AATD subjects with and without emphysema, bronchiectasis and chronic bronchitis using logistic regression controlling for age, gender, smoke exposure and presence of additional phenotypes. Qualitative outcomes were chosen where possible since they may be more informative in AATD[32]. Quantitative genetic association analysis was carried out for FEV1, FEV1/FVC, KCO, upper zone voxel index (UZVI) and lower zone voxel index (LZVI) using general linear models, accounting for covariates as before. Analyses of HRCT measures were only carried out in those with emphysema. Additive models were assumed for all SNPs. Plasma TNF $\alpha$ level was compared between genotypes for each associated SNP using regression controlling for age; no other covariates were significant in the models. 


\section{Results \\ Clinical phenotypes}

The clinical features of the whole group and of those with each sub-phenotype are shown in table 1 . The frequency of each qualitative phenotype within the subjects is shown in figure 1a, and the degree of overlap between them in figure 1b. Emphysematous subjects had smoked more than those without ( $\mathrm{p}<0.001)$. There was no difference in smoke exposure, lung function or UZVI between those with and without bronchiectasis, though affected subjects were older $(\mathrm{p}<0.001)$ and exhibited more severe lower zone emphysema $(\mathrm{p}=0.03)$. Subjects with chronic bronchitis had lower FEV1 ( $\mathrm{p}=0.01$ ) but no other demographic or clinical features differed. There were no gender differences between those with and without each of the qualitative phenotypes. The group assessed for decline of lung function showed no difference in any demographic or clinical features from the whole group, except that they had smoked slightly more ( $\mathrm{p}=0.030)$.

In the regression models age remained a significant predictor of both emphysema and bronchiectasis ( $\mathrm{B}=0.09$ and 0.05 respectively, both $\mathrm{p}<0.0001$ ), whilst pack years smoked was associated with emphysema $(\mathrm{B}=0.10, \mathrm{p}<$ $0.0001)$. No demographic or clinical features predicted the development of chronic bronchitis.

\section{Genetic associations}

Genotyping was successful in $95.3 \%$ of cases. All SNPs were in Hardy Weinberg equilibrium. Allele frequencies for each tag SNP are shown in table 2. A significant difference in allele frequency was seen between subjects with and without chronic bronchitis for rs361525 (both $\mathrm{p}=$ 0.01 ), with the A allele conferring an odds ratio (OR) of 2.08 (95\% confidence interval 1.18-3.67) in the regression analysis. In the regression analyses for presence of emphysema and bronchiectasis no tag SNP made a significant contribution. There were no tag SNP associations with lung function, emphysema severity or decline of FEV1. No haplotypes were observed for analysis.

\section{Plasma TNF $\alpha$ associations}

Plasma TNF $\alpha$ was significantly correlated with age $(\mathrm{r}=$ $0.21, \mathrm{p}=0.05$ ), but did not show any variation between sub-phenotypes or correlation with disease severity as measured by lung function or HRCT. A regression model controlling for age did not show any association of plasma level with rs361525 genotype, either in the whole group or the subgroup with chronic bronchitis. Levels in each sub-phenotype are shown in table 3.

\section{Discussion}

Our results show an association between the A allele of rs361525 subjects and chronic bronchitis in AATD. One previous study in COPD genetics has tagged TNF $\alpha[13]$ but did not find an association with rs361525. Subjects included a family cohort with airflow obstruction, and cases with emphysema. No previous studies in COPD have looked for association of chronic bronchitis with rs361525.

The importance of chronic bronchitis has been recognised by other COPD genetic association studies [14,33]. Its definition has been standardised for many years in respiratory medicine[22], but remains a historical definition, thus prone to problems with patient recall. Nevertheless it is an important phenotype to ascertain, as it may affect patient management: mucolytics may be more appropriate in the presence of a productive cough[34], and coexistence with an HRCT diagnostic of bronchiectasis might prompt addition of airway clearance measures. A high incidence of HRCT changes suggestive of bronchiectasis is seen in patients with emphysema[35] and it is not yet clear whether all such subjects should be managed as aggressively as those with typical symptomatology. Anti-TNF therapy has been disappointing in COPD[36], but was not assessed specifically in chronic bronchitis despite the importance of TNFa in the pathophysiology of the condition[9]. Furthermore, response to anti-TNF treatment may be dictated by TNF $\alpha$ genotype[37], perhaps indicating a need for further studies directed to sub-phenotype or genotype.

Although there is a degree of overlap of COPD phenotypes, our results are specific to chronic bronchitis, and concur with prior evidence regarding a role for TNF $\alpha$ in airways disease [9]. Such an association is lacking for presence or severity of parenchymal disease, defined by emphysema on HRCT. This suggests different genetic influences upon the development of each sub-phenotype and supports the view that inadequate patient characterisation may underlie poor replication of previous COPD genetic association studies. It is also of interest that the influence of age and smoke exposure differed between COPD phenotypes in the regression models, further emphasising differences in pathogenesis. Some markers of disease, notably CT densitometry, can become abnormal at or below the age of 20 in AATD[38], such that it was important for us to include all adult PiZZ subjects in our analyses. Despite maximising our numbers in this way we were unable to show any TNF $\alpha$ effect on quantitative phenotypes, again emphasising the specificity of association with chronic bronchitis.

Our reported genetic association in AATD may be explained by the interaction between TNF $\alpha$ and AAT. TNF $\alpha$ release is suppressed by AAT in vitro[21] and in animal models[39]. Consequently, TNF $\alpha$ effects may be more pronounced in AATD where this suppression is reduced. These epistatic effects resulting from cytokine 


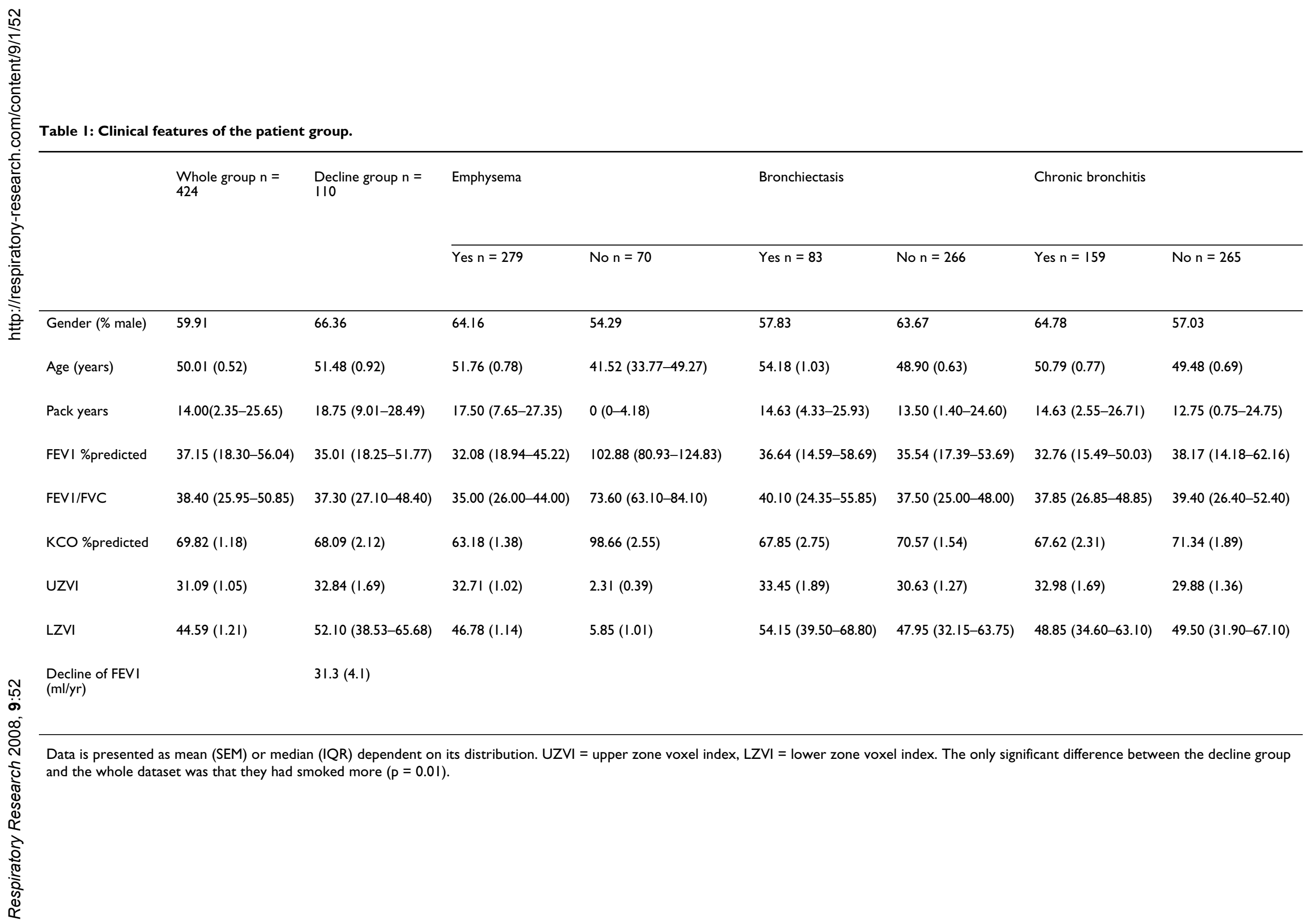


Table 2: Allele frequencies of tag SNPs.

\begin{tabular}{|c|c|c|c|c|}
\hline \multicolumn{5}{|c|}{ Minor Allele frequency (\%) (OR, $p$ value) } \\
\hline SNP [major allele, minor allele] & All & Chronic bronchitis & Emphysema & Bronchiectasis \\
\hline $\operatorname{rs} \mid 800629[\mathrm{G}, \mathrm{A}]$ & 21.73 & 24.32 & 21.97 & 26.58 \\
\hline $\mathrm{rs} 36 \mid 525[\mathrm{G}, \mathrm{A}]$ & 8.60 & $11.76(2.08,0.01)$ & 8.24 & 5.00 \\
\hline rs I $799964[\mathrm{~T}, \mathrm{C}]$ & 25.32 & 26.69 & 25.10 & 26.58 \\
\hline rs3093662 [A, G] & 8.91 & 11.33 & 8.17 & 4.55 \\
\hline
\end{tabular}

Odds ratio $(O R)$ and $p$ value are given in parentheses for significant associations only.

interactions have previously been reported in asthma in which multiple polymorphisms in genes involved in the Th2 immune response, rather than individual SNPs appear to increase the risk of disease [40].

rs361525 (G-238A) is located in the promoter region of TNF $\alpha$ and has been studied extensively in many different disease states, although little evidence exists for a functional effect. Cellular studies of $T N F \alpha$ promoter region SNPs suggest that G-238A increases gene transcription [41]. Conversely gene expression in patients with psoriasis (a disease with which the -238 A allele is strongly associated[42]) appears reduced [43]. Further functional work clarifying the role of rs361525 would be indicated if fine mapping of the region surrounding it confirmed it to be the functional variant associated with disease, rather than merely a polymorphism in linkage disequilibrium. Such studies are expensive, and alternative surrogate support for a functional effect may be gained by assessing plasma $\mathrm{TNF} \alpha$ levels [44]. In the current study no association was found between rs361525 genotype and plasma TNF $\alpha$ levels. This may be because of the specific association with airways disease since airway and plasma inflammatory markers do not correlate in COPD [45]. However many factors influence airway inflammation in COPD, including bacterial colonisation[46] and cachexia [10] so any study of genetic association with airway inflammatory markers would require matching of subjects for these features.

The TNF $\alpha$ promoter region is in strong LD with HLA class II alleles in Caucasians [47], particularly between rs1800629 and the HLA DR3 haplotype. This has not

Table 3: Plasma TNF $\alpha$ levels in AATD subjects.

\begin{tabular}{ll}
\hline & Plasma TNF $\alpha(\mathrm{pM})$ \\
\hline All subjects & $0.074(0.004)$ \\
Emphysema & $0.079(0.005)$ \\
Bronchiectasis & $0.089(0.012)$ \\
Chronic bronchitis & $0.078(0.007)$ \\
\hline
\end{tabular}

Data is expressed as mean (SEM). been observed for rs361525, therefore it is unlikely that our results are due to LD with HLA alleles.

The results reported in our study are without adjustment for multiple statistical testing as corrections such as Bonferroni appear overly conservative in genetic association studies [48], hence are inappropriate. This is particularly true when several theories are being tested, as in our study in which we hypothesised that each SNP could be driving any of three qualitative COPD phenotypes, or affecting disease severity via several quantitative phenotypes. Statistical significance has been proposed if it reaches the level needed for a genome wide study (generally considered to be $\mathrm{p} \leq 5 \times 10^{-5}[48]$ ), or by replication in an independent population. We have considered the latter approach: a second small familial dataset does exist in the UK that could act as a replication group. However, within this dataset there is no difference in the prevalence of chronic bronchitis between family members [49]. As such we would be unable to test our hypothesis in this cohort. These challenges are inherent in studying AATD, as recruitment of datasets powered for genome wide significance using healthy AATD controls may be impossible, because of the high rates of disease phenotypes (see Figure 1a). International collaborations to create larger datasets could certainly help overcome this problem although geographical variation of genes, particularly those within the HLA region such as TNF $\alpha$, may be a further confounding factor [50].

\section{Conclusion}

The current study conducted on the UK national registry of AATD presents data to indicate that variation in TNF $\alpha$ influences phenotype in AATD. It further supports the hypothesis that the range of COPD phenotypes may be driven by specific underlying genetic susceptibilities in a similar manner to usual COPD. 


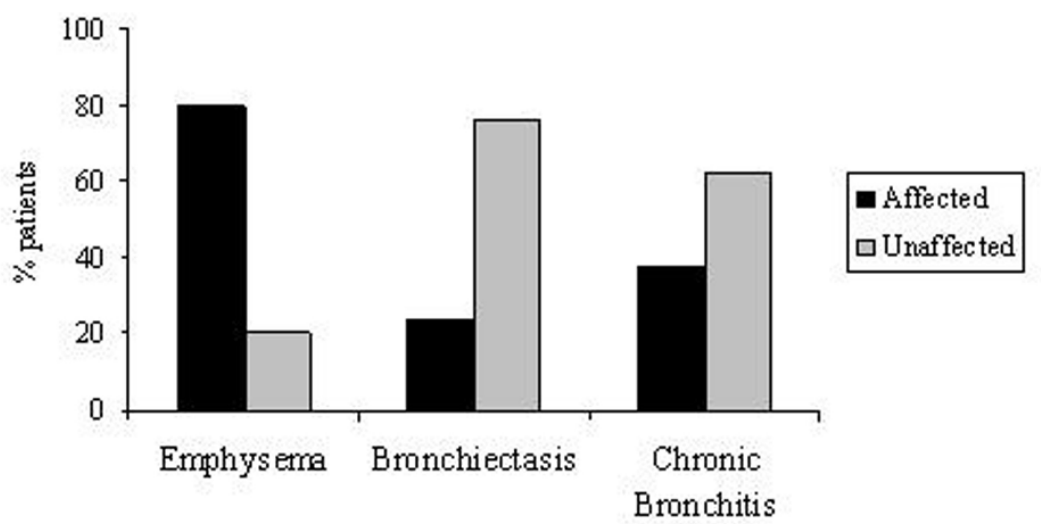

Figure la: Frequency of phenotypes in AATD patients

Chronic bronchitis $\mathrm{n}=159$

Bronchiectasis $\mathrm{n}=83$

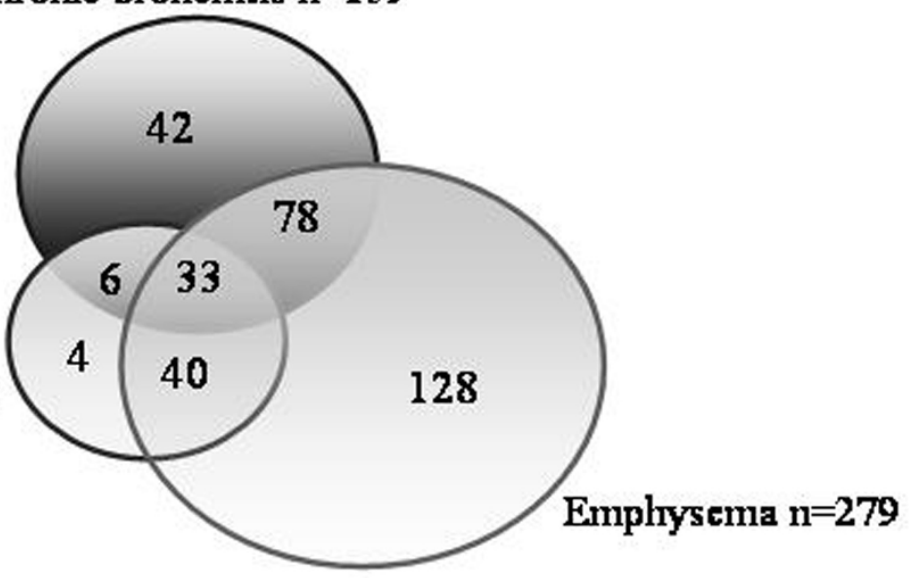

Figure lb: Phenotypic overlap in AATD patients

Figure I

text

\section{Competing interests}

The authors declare that they have no competing interests.

\section{Authors' contributions}

AMW assessed clinical phenotypes, conducted laboratory procedures, analysed data and drafted the manuscript. PRN and DLB assisted and supervised laboratory procedures. MJS, SCG and RAS supervised the project and reviewed the manuscript.

\section{Acknowledgements}

The authors are supported by funding from Talecris Biotheraputics and the Wellcome Trust, neither of whom had any involvement in study design or conduct, manuscript preparation or submission.

\section{References}

I. ATS: Cigarette smoking and health. Am J Respir Crit Care Med I996, I 53(2):861-865.
2. Lewitter FI, Tager IB, McGue M, Tishler PV, Speizer FE: Genetic and environmental determinants of level of pulmonary function. Am J Epidemiol 1984, I 20(4):5 I8-530.

3. Kueppers F, Miller RD, Gordon H, Hepper NG, Offord K: Familial prevalence of chronic obstructive pulmonary disease in a matched pair study. Am J Med 1977, 63(3):336-342.

4. Fletcher $C$, Peto R: The natural history of chronic airflow obstruction. $\mathrm{Br}$ Med J 1977, I (6077): I645-1648.

5. Stockley RA: Neutrophils and protease/antiprotease imbalance. Am J Respir Crit Care Med 1999, $160(5$ Pt 2):S49-52.

6. MacNee W: Oxidants/antioxidants and COPD. Chest 2000, I I7(5 Suppl I):303S-17S.

7. Sevenoaks MJ, Stockley RA: Chronic Obstructive Pulmonary Disease, inflammation and co-morbidity--a common inflammatory phenotype? Respir Res 2006, 7:70.

8. Keatings VM, Collins PD, Scott DM, Barnes PJ: Differences in interleukin-8 and tumor necrosis factor-alpha in induced sputum from patients with chronic obstructive pulmonary disease or asthma. Am J Respir Crit Care Med 1996, I 53(2):530-534.

9. Mueller R, Chanez P, Campbell AM, Bousquet J, Heusser C, Bullock GR: Different cytokine patterns in bronchial biopsies in asthma and chronic bronchitis. Respir Med 1996, 90(2):79-85.

10. Di Francia M, Barbier D, Mege JL, Orehek J: Tumor necrosis factor-alpha levels and weight loss in chronic obstructive pul- 
monary disease. Am J Respir Crit Care Med 1994, I50(5 Pt I): $|453-| 455$

II. Sakao S, Tatsumi K, Igari H, Shino Y, Shirasawa H, Kuriyama T: Association of tumor necrosis factor alpha gene promoter polymorphism with the presence of chronic obstructive pulmonary disease. Am J Respir Crit Care Med 200I, 163(2):420-422.

12. Sakao S, Tatsumi K, Igari H, Watanabe R, Shino Y, Shirasawa H, Kuriyama $\mathrm{T}$ : Association of tumor necrosis factor-alpha gene promoter polymorphism with low attenuation areas on highresolution CT in patients with COPD. Chest 2002, I 22(2):416-420.

13. Hersh CP, Demeo DL, Lange C, Litonjua AA, Reilly JJ, Kwiatkowski D, Laird N, Sylvia JS, Sparrow D, Speizer FE, Weiss ST, Silverman EK: Attempted replication of reported chronic obstructive pulmonary disease candidate gene associations. Am J Respir Cell $\mathrm{Mol}$ Biol 2005, 33(I):71-78.

14. Huang SL, Su CH, Chang SC: Tumor necrosis factor-alpha gene polymorphism in chronic bronchitis. Am J Respir Crit Care Med 1997, I56(5): 1436-1439.

15. Needham M, Stockley RA: Alpha I-antitrypsin deficiency. 3: Clinical manifestations and natural history. Thorax 2004, 59(5):44|-445.

16. Rodriguez F, de la Roza C, Jardi R, Schaper M, Vidal R, Miravitlles M: Glutathione S-transferase $P I$ and lung function in patients with alphal-antitrypsin deficiency and COPD. Chest 2005, I 27(5): 1537-1543.

17. Silverman EK, Province MA, Campbell EJ, Pierce JA, Rao DC: Variability of pulmonary function in alpha-I-antitrypsin deficiency: residual family resemblance beyond the effect of the Pi locus. Hum Hered 1990, 40(6):340-355.

18. Demeo DL, Campbell EJ, Barker AF, Brantly ML, Eden E, McElvaney NG, Rennard SI, Sandhaus RA, Stocks JM, Stoller JK, Strange C, Turino G, Silverman EK: ILIO Polymorphisms are Associated with Airflow Obstruction in Severe alpha I-antitrypsin Deficiency. Am J Respir Cell Mol Biol 2007.

19. Novoradovsky A, Brantly ML, Waclawiw MA, Chaudhary PP, Ihara H, Qi L, Eissa NT, Barnes PM, Gabriele KM, Ehrmantraut ME, Rogliani P, Moss J: Endothelial nitric oxide synthase as a potential susceptibility gene in the pathogenesis of emphysema in alphalantitrypsin deficiency. American journal of respiratory cell and molecular biology 1999, 20(3):44|-447.

20. Hill AT, Campbell EJ, Bayley DL, Hill SL, Stockley RA: Evidence for excessive bronchial inflammation during an acute exacerbation of chronic obstructive pulmonary disease in patients with alpha(I)-antitrypsin deficiency (PiZ). Am J Respir Crit Care Med 1999, 160(6): 1968-1975.

21. Churg A, Wang X, Wang RD, Meixner SC, Pryzdial EL, Wright JL: \{alpha\}-I-Antitrypsin Suppresses TNF $\{$ alpha\} and MMP-I2 Production by Cigarette Smoke-Stimulated Macrophages. Am J Respir Cell Mol Biol 2007.

22. Definition and classification of chronic bronchitis for clinical and epidemiological purposes. A report to the Medical Research Council by their Committee on the Aetiology of Chronic Bronchitis. Lancet 1965, I(7389):775-779.

23. Dowson LJ, Guest PJ, Hill SL, Holder RL, Stockley RA: High-resolution computed tomography scanning in alphal-antitrypsin deficiency: relationship to lung function and health status. Eur Respir J 200I, I 7(6): I097-I I 04

24. Naidich DP, McCauley DI, Khouri NF, Stitik FP, Siegelman SS: Computed tomography of bronchiectasis. Journal of computer assisted tomography 1982, 6(3):437-444

25. Muller NL, Staples CA, Miller RR, Abboud RT: "Density mask". An objective method to quantitate emphysema using computed tomography. Chest 1988, 94(4):782-787.

26. Holme J, Stockley RA: Radiologic and clinical features of COPD patients with discordant pulmonary physiology: lessons from alpha I-antitrypsin deficiency. Chest 2007, I32(3):909-915.

27. Soejima K, Yamaguchi K, Kohda E, Takeshita K, Ito Y, Mastubara H, Oguma T, Inoue T, Okubo Y, Amakawa K, Tateno H, Shiomi T: Longitudinal follow-up study of smoking-induced lung density changes by high-resolution computed tomography. American journal of respiratory and critical care medicine 2000, I6I(4 Pt I): $1264-1273$.

28. Simmonds MJ, Heward JM, Howson JM, Foxall $H$, Nithiyananthan $R$, Franklyn JA, Gough SC: A systematic approach to the assess- ment of known TNF-alpha polymorphisms in Graves' disease. Genes Immun 2004, 5(4):267-273.

29. Newby PR, Roberts-Davies EL, Brand OJ, Heward JM, Franklyn JA, Gough SC, Simmonds MJ: Tag SNP screening of the PDCDI gene for association with Graves' disease. Clinical endocrinology 2007, 67(I): 125-128.

30. Sapey E, Bayley D, Ahmad A, Newbold P, Snell N, Stockley RA: Interrelationships between inflammatory markers in stable COPD patients with bronchitis: the intra and inter patient variability. Thorax 2007.

31. Barrett JC, Fry B, Maller J, Daly MJ: Haploview: analysis and visualization of LD and haplotype maps. Bioinformatics (Oxford, England) 2005, 2 I (2):263-265

32. Silverman EK, Mosley JD, Rao DC, Palmer LJ, Province MA, Elston RC, Weiss ST, Campbell E): Linkage analysis of alpha I-antitrypsin deficiency: lessons for complex diseases. Hum Hered 200I, 52(4):223-232.

33. Baranova H, Perriot J, Albuisson E, Ivaschenko T, Baranov VS, Hemery B, Mouraire P, Riol N, Malet P: Peculiarities of the GSTMI 0/ 0 genotype in French heavy smokers with various types of chronic bronchitis. Hum Genet 1997, 99(6):822-826.

34. Management of chronic obstructive pulmonary disease in adults in primary and secondary care [http://www.nice.org.uk/ pdf/CGOI2 nicceguideline.pdf]

35. Parr DG, Guest PG, Reynolds JH, Dowson LJ, Stockley RA: Prevalence and impact of bronchiectasis in alphal-antitrypsin deficiency. Am J Respir Crit Care Med 2007, I 76( I 2): |2 I5-I22I.

36. Rennard SI, Fogarty C, Kelsen S, Long W, Ramsdell J, Allison J, Mahler D, Saadeh C, Siler T, Snell P, Korenblat P, Smith W, Kaye M, Mandel M, Andrews C, Prabhu R, Donohue JF, Watt R, Lo KH, SchlenkerHerceg R, Barnathan ES, Murray J: The safety and efficacy of infliximab in moderate to severe chronic obstructive pulmonary disease. Am J Respir Crit Care Med 2007, I75(9):926-934.

37. Seitz M, Wirthmuller U, Moller B, Villiger PM: The -308 tumour necrosis factor-alpha gene polymorphism predicts therapeutic response to TNFalpha-blockers in rheumatoid arthritis and spondyloarthritis patients. Rheumatology (Oxford, England) 2007, 46(I):93-96.

38. Holme J, Stockley JA, Stockley RA: When should we start monitoring alpha I antitrypsin deficient subjects?: London. Volume 62.; 2007:Al40.

39. Wright JL, Farmer SG, Churg A: Synthetic serine elastase inhibitor reduces cigarette smoke-induced emphysema in guinea pigs. Am J Respir Crit Care Med 2002, 166(7):954-960.

40. Howard TD, Koppelman GH, Xu J, Zheng SL, Postma DS, Meyers DA, Bleecker ER: Gene-gene interaction in asthma: IL4RA and ILI 3 in a Dutch population with asthma. Am J Hum Genet 2002, 70(I):230-236.

4I. Bayley JP, de Rooij H, van den Elsen PJ, Huizinga TW, Verweij CL: Functional analysis of linker-scan mutants spanning the -376 , $-308,-244$, and -238 polymorphic sites of the TNF-alpha promoter. Cytokine 200I, I 4(6):3 I6-323.

42. Rahman P, Siannis F, Butt C, Farewell V, Peddle L, Pellett F, Gladman $D$ : TNFalpha polymorphisms and risk of psoriatic arthritis. Annals of the rheumatic diseases 2006, 65(7):919-923.

43. Kaluza W, Reuss E, Grossmann S, Hug R, Schopf RE, Galle PR, Maerker-Hermann E, Hoehler T: Different transcriptional activity and in vitro TNF-alpha production in psoriasis patients carrying the TNF-alpha 238A promoter polymorphism. The Journal of investigative dermatology 2000, I | 4(6): I I80-I I83.

44. Demeo DL, Campbell EJ, Barker AF, Brantly ML, Eden E, McElvaney NG, Rennard SI, Sandhaus RA, Stocks JM, Stoller JK, Strange C, Turino G, Silverman EK: ILIO polymorphisms are associated with airflow obstruction in severe alphal-antitrypsin deficiency. Am J Respir Cell Mol Biol 2008, 38(I): I I4-I20.

45. Vernooy JH, Kucukaycan M, Jacobs JA, Chavannes NH, Buurman WA, Dentener MA, Wouters EF: Local and systemic inflammation in patients with chronic obstructive pulmonary disease: soluble tumor necrosis factor receptors are increased in sputum. Am J Respir Crit Care Med 2002, 166(9): | 2 I8-1224.

46. Sethi S, Maloney J, Grove L, Wrona C, Berenson CS: Airway inflammation and bronchial bacterial colonization in chronic obstructive pulmonary disease. Am J Respir Crit Care Med 2006, I73(9):99|-998.

47. Wilson AG, de Vries N, Pociot F, di Giovine FS, van der Putte LB, Duff GW: An allelic polymorphism within the human tumor 
necrosis factor alpha promoter region is strongly associated with HLA AI, B8, and DR3 alleles. J Exp Med 1993, I77(2):557-560.

48. Colhoun HM, McKeigue PM, Davey Smith G: Problems of reporting genetic associations with complex outcomes. Lancet 2003, 36 I (9360):865-872.

49. Wood AM, Stockley RA: Phenotypic characteristics of alpha I antitrypsin deficient sibling pairs show discordance: Toronto. Volume 176.; 2008:A418.

50. WTCCC: Genome-wide association study of $\mathbf{1 4 , 0 0 0}$ cases of seven common diseases and 3,000 shared controls. Nature 2007, 447(7| I45):66I-678.

Publish with Bio Med Central and every scientist can read your work free of charge

"BioMed Central will be the most significant development for disseminating the results of biomedical research in our lifetime. "

Sir Paul Nurse, Cancer Research UK

Your research papers will be:

- available free of charge to the entire biomedical community

- peer reviewed and published immediately upon acceptance

- cited in PubMed and archived on PubMed Central

- yours - you keep the copyright

Submit your manuscript here:

http://www.biomedcentral.com/info/publishing_adv.asp 